\title{
Artificial neural network for ecological-economic zoning as a tool for spatial planning
}

\author{
Luis Waldyr Rodrigues Sadeck(1), Aline Maria Meiguins de Lima(1) and Marcos Adami(2)
}

\begin{abstract}
(1)Universidade Federal do Pará, Rua Augusto Corrêa, no 01, Guamá, CEP66075-110 Belém, PA, Brazil. E-mail: luissadeck_w@yahoo.com.br, ameiguins@ufpa.br (2)Instituto Nacional de Pesquisas Espaciais, Centro Regional da Amazônia, Parque de Ciência e Tecnologia do Guamá, Avenida Perimetral, no 2.651, CEP 66077-830 Belém, PA, Brazil. E-mail: marcos.adami@inpe.br
\end{abstract}

\begin{abstract}
The objective of this work was to analyze social and environmental information through an artificial neural network-self-organizing map (ANN-SOM), in order to provide subsidy to ecologicaleconomic zoning (EEZ) as a tool to reduce the subjectivity of the process. The study area comprises 16 municipalities in the northeast of the state of Pará, Brazil, representative of the agricultural development in the state. Data processing involved three steps: preparation of the data in a geographic information system (GIS) environment; mathematical processing (ANN-SOM) of the data; and visualization and interpretation of the processing results, allowing the spatial planning of northeastern Pará. The results comprised 13 classes, regrouped according to behavioral similarity criteria into four categories, which represent the main areas of sustainability proposed for the state of Pará, according to existing EEZ. The proposed methodology allows individualizing areas in the region that EEZ had not defined, mainly due to the greater possibility of combining and integrating a large number of physical, social, and economic variables through the SOM.
\end{abstract}

Index terms: Amazon, regional planning, regionalization, self-organizing maps.

\section{Rede neural artificial para o zoneamento ecológico-econômico como instrumento de ordenamento territorial}

\begin{abstract}
Resumo - O objetivo deste trabalho foi analisar informações socioambientais por meio de rede neural artificial-mapa auto-organizável (RNA-SOM), para fornecer subsídio ao zoneamento ecológico econômico (ZEE) como instrumento para diminuir a subjetividade do processo. A área de estudo compreende 16 municípios do Nordeste Paraense, expressivos no desenvolvimento agropecuário do estado. O tratamento dos dados envolveu três etapas: preparação dos dados em ambiente de sistema de informação geográfica (SIG); processamento matemático (RNA-SOM) dos dados; e visualização e interpretação dos resultados dos processamentos, o que permitiu o ordenamento territorial do Nordeste Paraense. Os resultados compreenderam 13 classes, reagrupadas de acordo com critérios de similaridade de comportamento em quatro categorias, que representam os principais eixos de sustentabilidade propostos para o Estado do Pará, a partir do ZEE existente. A metodologia proposta permite individualizar zonas na região que o ZEE não havia definido, principalmente em razão da maior possibilidade de conjugar e integrar um grande número de variáveis físicas, sociais e econômicas por meio do SOM.
\end{abstract}

Termos para indexação: Amazônia, planejamento regional, regionalização, mapas auto-organizáveis.

\section{Introduction}

In the last three decades, there has been a great increase in the availability of satellite images and of environmental and socioeconomic data, which can be used as a subsidy by the environmental sciences to understand and solve problems (Pozzebon et al., 2015; Reis et al., 2015). This increase is associated with technological development, mainly in areas linked to computing, which allows working with large amounts of data, facilitating their generation, storage, retrieval, and analysis. It should be noted that these large volumes of data include both the spatial and temporal dimensions (Bacani et al., 2015).

The computational tools geared towards spatial planning aim to promote a sustainable appropriation of the territory and to reconcile the need of expansion of the productive sector with environmental sustainability (Hayes \& Rajão, 2011). This allows maintaining essential areas of specific ecosystems, whose functions are associated with the preservation of fauna and flora, as well as biogeochemical cycles (Martins et al., 2015). 
In this context, ecological-economic zoning (EEZ) has the direct purpose of integrating socioeconomic development and environmental preservation/ conservation (Souza \& Medeiros, 2003; Pereira et al., 2011). However, the used methodologies make it difficult to integrate the large amount of data necessary for spatial planning by EEZ. This turns the process slow because there is a need for adjustments in the spatial and temporal scales (same period of acquisition) of the data used (Becker, 2005).

The development of geographic information systems (GIS) has aided in the development of EEZ. However, the achievements in this field are still incipient, combining geospatial techniques with computational technologies, despite showing considerable advances in analysis algorithms, as highlighted by Brown \& Fagerholm (2015), who listed the techniques used from 1998 to 2014 for mapping. These processes have been responsible for great advances in exploring the results that integrate geographic space complexities, related to the planning and management of human activities (Tornquist et al., 2009). However, up to the present study, there are no known reports on the joint use of GIS, EEZ, and artificial neural networks (ANNs), more specifically with a self-organizing map (SOM).

Regarding the development of analysis algorithms, the ANNs-SOMs are able to integrate large amount of data (Arruda et al., 2013; Leal et al., 2015) and are very promising to support analyzes focused on the zoning or regionalization methodology, which encompasses environmental diversity and socioeconomic potential (Spörl et al., 2011). In addition, ANNs are more robust in the presence of noise and do not suffer some of the limitations of the algorithms based on statistics, mostly related to the non-linearity or heteroscedasticity of the data.

Currently, the EEZ methods are characterized by exhaustive technical queries, and the GIS is used to analyze the obtained data and compose zones. However, this process still involves much subjectivity, which can make EEZ more of a political instrument than an economic and ecological one.

The present work proposes the use of an ANN-SOM as an innovation in the development of EEZ, aiming to minimize subjectivity and reduce the time involved in the construction process of the synthesis map for territory management.
The objective of this work was to analyze social and environmental information through an ANN-SOM, in order to provide subsidy to EEZ as a tool to reduce the subjectivity of the process.

\section{Materials and Methods}

The study area comprises 16 municipalities in the northeast region of the state of Pará (Figure 1), Brazil, which was performed with data from IBGE (2014a). Although this region is one of the pioneer fronts of the state, it is already characterized by heavy forest conversion into agricultural areas and pasture. Besides, some of the municipalities are among the ten that contribute the most to the agriculture and livestock sectors, making the area fundamental for spatial planning, indicative of sustainable development.

The physical input variables used were: rainfall; geomorphology; geology; land use; soil and plant cover; and socioeconomic variables, such as rural and urban population, total human development index (HDI), GINI index, energy and water supply (Table 1). These variables were chosen following the guidelines for EEZ, which were used to map the natural vulnerability to soil loss (Crepani et al., 2001) and the ecological-economic zones of states in the Legal Amazon (Detalhamento... 1996; Brasil, 2010).

Data processing involved three steps: preparation of the data in a GIS environment; mathematical processing (ANN-SOM) of the data; and visualization and interpretation of the processing results (Figure 2), described as follows.

The database was created using the open-source object-relational database manager, PostgreSQL (2014); then, the vector bases were inserted via the GIS TerraView, version 4.2.2 (INPE, 2014).

The following geographic operations were also carried out in the GIS environment: intersection of environmental data with each other and with municipal boundaries; dissolution of polygons with equal and touching classes, in order to minimize the number of polygons; insertion of map weights following the EEZ document (Crepani et al., 2001), including the values of vulnerability to soil loss of the thematic classes and the socioeconomic data of each polygon, as well as the association of the values of socioeconomic potential of each polygon in each municipality (Detalhamento..., 1996; Crepani et al., 2001).

Pesq. agropec. bras., Brasília, v.52, n.11, p.1050-1062, nov. 2017 DOI: $10.1590 / \mathrm{S} 0100-204 \mathrm{X} 2017001100011$ 
To avoid the dimension of data from affecting the ANN results, all variables were normalized to continuous values between 0 and 1 , avoiding one dimension from overlapping another. The environmental data were normalized by a simple linear transformation, using the maximum value as a divisor. However, the socioeconomic data with values between 0 and 1 were not normalized, as in the case of the HDI. Percentages were divided by 100 . The classes use and occupation were normalized using the hierarchical analysis technique (Saaty, 1991), in which each of the 16 classes of TerraClass was adjusted in the matrix of preference taking into account what most favors environmental preservation and conservation.
It should be pointed out that the polygons belonging to the class "not observed" in land use and cover mapping (Almeida et al., 2016) were removed from the analysis, in order to avoid inappropriate classification.

The ANN-SOM consists of two layers: input layer I and output layer U. Each input in the network corresponds to a vector with parameters that will be mapped on the neurons. Each neuron of the output layer has a vector associated with the input vector, making it possible to map the source of the data. The fundamental parameters for the development of this algorithm are: continuous input space, which, by means of probability, selects the set of characteristics to approximate the distribution of the data; topology in the

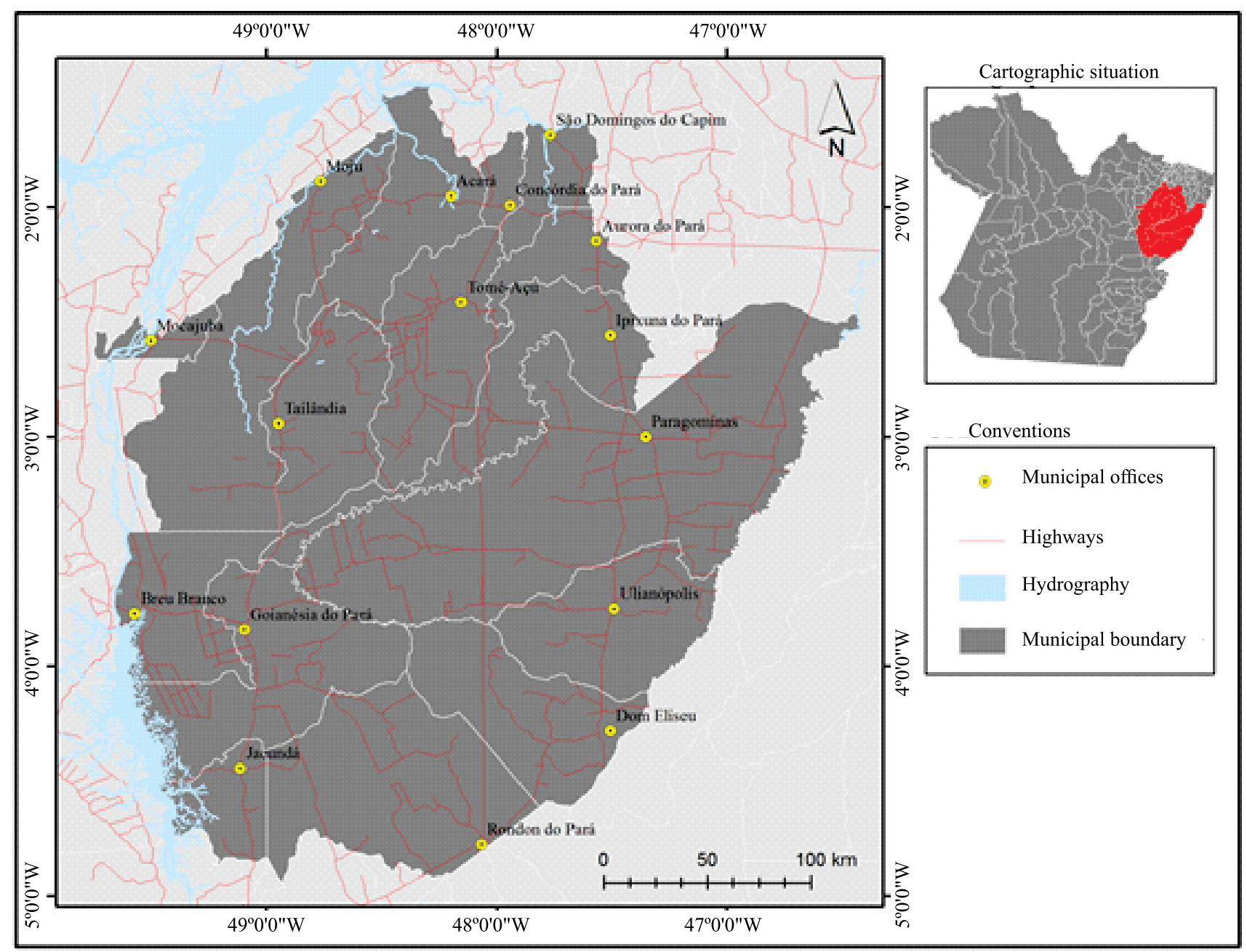

Figure 1. Study area represented by the following 16 municipalities of the northeast region of the state of Pará, Brazil: Acará, Aurora do Pará, Breu Branco, Concórdia do Pará, Dom Eliseu, Goianésia do Pará, Ipixuna do Pará, Jacundá, Mocajuba, Moju, Paragominas, Rondon do Pará, São Domingos do Capim, Tailândia, Tomé-Açu, and Ulianópolis.

Source: IBGE (2014a). 
Table 1. Data and software used in the research.

\begin{tabular}{|c|c|c|c|c|}
\hline & Material & Scale & File type $^{(1)}$ & Source \\
\hline Use and coverage 2010 & Vector basis of land use and cover & $1: 100000$ & $\operatorname{shp}$ & CRA (2014) \\
\hline \multirow[t]{3}{*}{$\begin{array}{l}\text { Socioeconomic data } \\
2010\end{array}$} & $\begin{array}{l}\text { Vector and numerical data associated with } \\
\text { socioeconomic information (population, economic } \\
\text { activities, territorial boundaries...) }\end{array}$ & Municipality & $\begin{array}{l}\text { xlsx and } \\
\text { shp }\end{array}$ & $\begin{array}{l}\text { IBGE (2014b) and } \\
\text { PNUD (2014) }\end{array}$ \\
\hline & soil (psolo) & $1: 250000$ & shp & Brasil (2014) \\
\hline & Rainfall (pclima) & Jan./Dec. & shp & NASA (2014) \\
\hline \multirow[t]{3}{*}{ Environmental data } & Geological units (pgeo) & $1: 250000$ & shp & Brasil (2014) \\
\hline & Cover vegetation (pveg) & $1: 250000$ & shp & Brasil (2014) \\
\hline & Geomorphological units (pgeom) & $1: 250000$ & $\operatorname{shp}$ & Brasil (2014) \\
\hline PRODES 2010 & Information on deforestation in the Amazon & $1: 250000$ & shp & OBT (2014) \\
\hline Cartographic base & Drainage network, access roads, municipal offices & $1: 250000$ & $\operatorname{shp}$ & IBGE (2014a) \\
\hline PostgreSQL/PostGIS & Spatial database manager & - & - & PostgreSQL (2014) \\
\hline TerraView 4.2.2 & Georeferencing and spatial analysis & - & - & INPE (2014) \\
\hline MatLAB & Information processing & - & - & MATLAB (2014) \\
\hline SOM Toolbox 2.0 & Information processing & - & - & Helsinki University of Technology (2014) \\
\hline
\end{tabular}

${ }^{(1)} \mathrm{shp}$, shapefile; and xlsx, Excel spreadsheet.

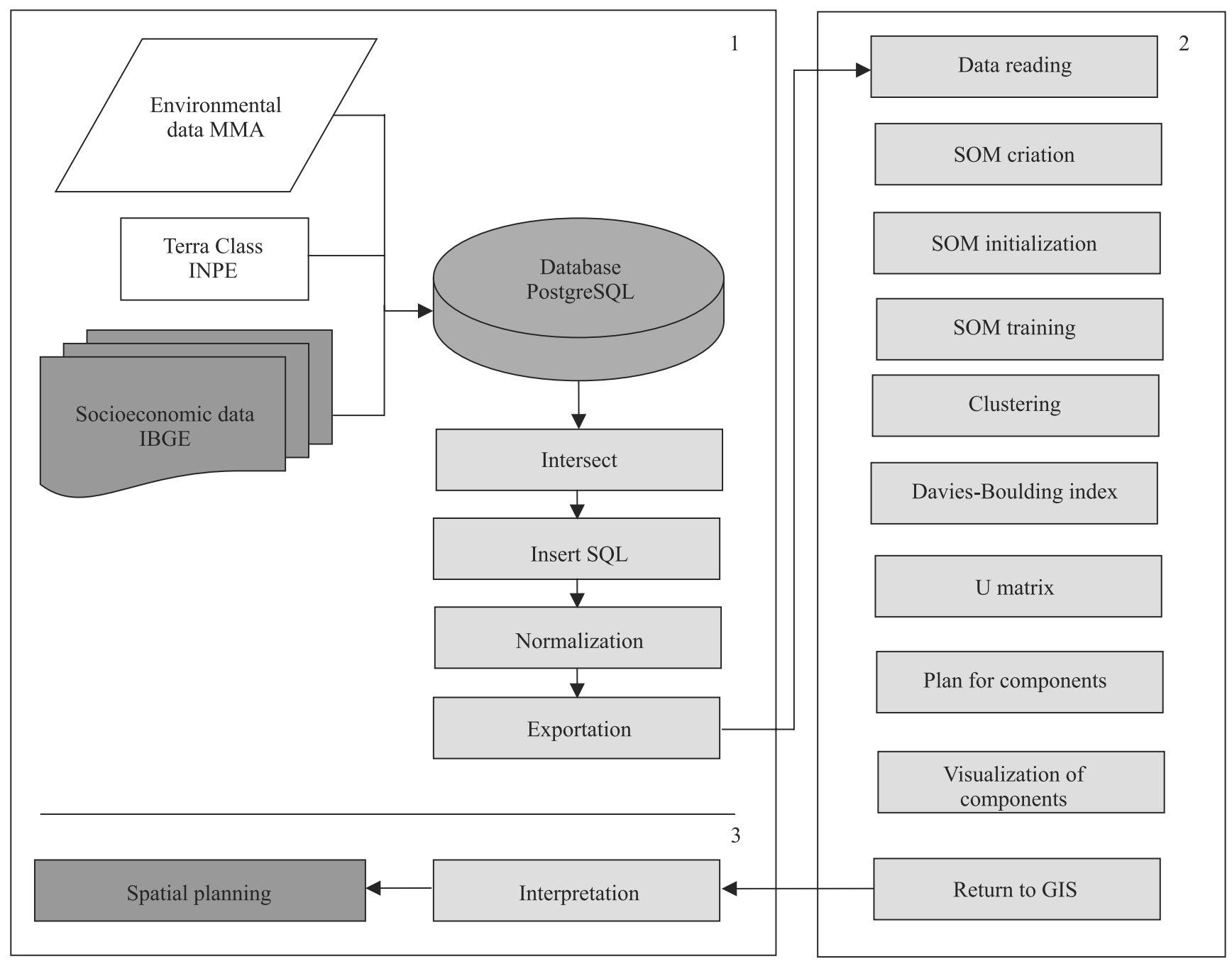

Figure 2. Methodological procedure for data treatment in the research: 1, preparation of the data in a GIS environment; 2, mathematical processing (ANN - SOM) of the data; and, 3, visualization and interpretation of the processing results. 
form of a grid of neurons that defines a discrete output space; Gaussian neighborhood function centered on the winning neuron; and learning rate parameter with a given initial value and that decreases gradually over time, but never reaches zero. The U-matrix represents the distances between each neuron and its neighbors (Vesanto et al., 2000).

The steps followed were: obtaining the data; pre-processing of the data; parameterization of the network; choice of the neural map size; and validation and interpretation of the results.

In ANN-SOM formatting, the structural matrix, containing the identifiers and the header, and the data matrix with 298,302 input polygons, containing the numerical data on which the calculations were made, were split. This formatting was used to create the structure for initialization, training, and errorchecking in the SOM.

In the validation process, the Davies-Bouldin index was used. This index evaluates the similarity between the clusters generated by the k-means algorithm, and takes into account the quantities and characteristics inherent to the data set, being basically made up by the Euclidean distance between the centroids of each grouping (Davies \& Bouldin, 1979; Vesanto et al., 2000).

Following the procedures of the EEZ methodology, established by Detalhamento... (1996), Veríssimo \& Souza (2006) and Pará (2012) the classes were grouped into four reference zones based on their socioeconomic, environmental, and legal characteristics. This was done to express the levels of restriction regarding the consolidation, conservation, recovery, and expansion of each area, in order to organize activities in the territory.

\section{Results and Discussion}

The intersection between environmental and socioeconomic data resulted in 298,302 polygons exempt from null values. When performing SOM, these polygons were grouped using 2,760 class centers for the production of the U-matrix and of the matrixes of the components with $69 \times 40$ dimensions. This means that, on average, each class center is associated with 108 polygons. At the end of training, the network grouped the data into 13 classes (Figure 3), described in Table 2. The quantization error was 0.102 , and the topological error was 0.192 . The lowest value $(0.7265)$ of the Davies-Bouldin index was found when the neurons were grouped into 13 distinct classes. For the studied region, the total processing time until obtaining four distinct classes was of three days, whereas, using traditional procedures, with EEZ, it takes an average of one to two years (Brasil, 2010). Moreover, subjectivity in the generation of the 13 classes was removed in the present study, since the process was carried out by machine learning, which made it a technical interpretation of aggregation for the four classes of EEZ.

The result of the clusters presented in the U-matrix were spatialized (Figure 4). The spatial distribution of the classes shows that the areas with a high population index and that present environmental conditions with low vulnerability - such as the municipalities of Paragominas and Tailândia (class 7) and a large southern portion of the study area (class 8) - were grouped correctly. The river environment was well defined, and the analyses of the classes proved them to be areas suitable for recovery/conservation. The areas to the north of the assessed region, due to rural population density, low infrastructure, and stable environmental conditions, were grouped into class 4 , and, when studying the attributes of this class, it was verified that these areas should receive greater incentives for the expansion of economic activities.

The obtained classes were then distributed into groups according to four categories (Figure 5): consolidation, recovery, expansion, and conservation. This was done by the ad hoc method (Woodward, 2011), which is based on the empirical knowledge of experts on the subject matter and/or on the area in question. These classes were distributed in the summary graph of subsidies for territory management according to the given weights (Detalhamento..., 1996; Crepani et al., 2001; Brasil, 2006; Silva et al., 2014b) and to the characterization of the classes as to potential and vulnerability.

It was observed that classes $1,5,6$, and 10 , when analyzed taking into account environmental issues, include areas with high vulnerability to soil loss and low socioeconomic potential. Therefore, these areas must be conserved, aiming sustainable territorial management in the permanent protection category, since they have high biological diversity and also 


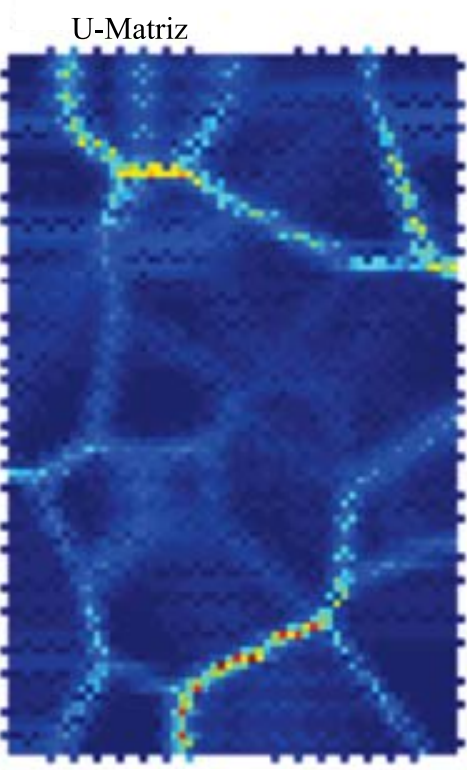

$69 \times 40$

2760
Dissimilarity

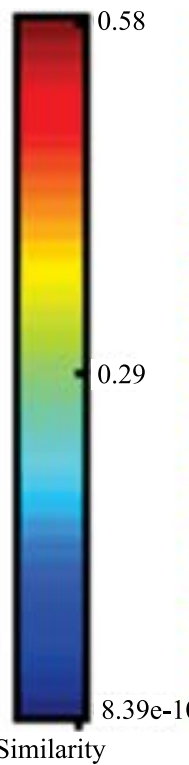

Similarity
Classes

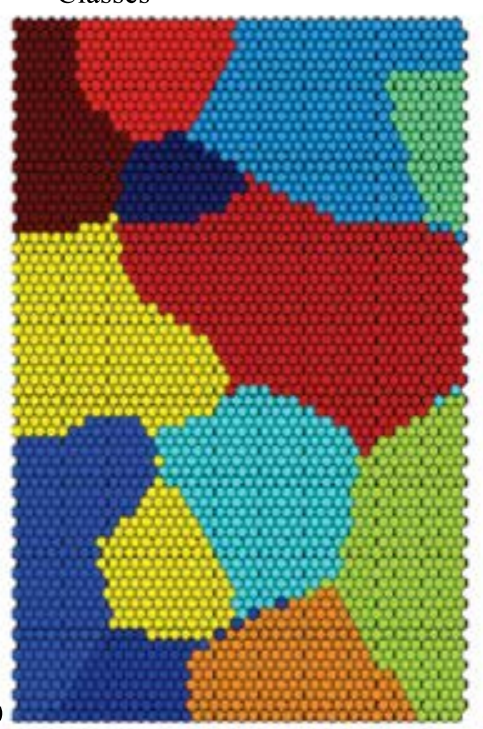

Validation

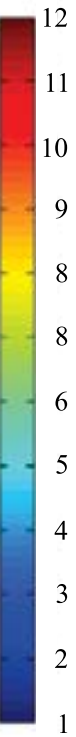

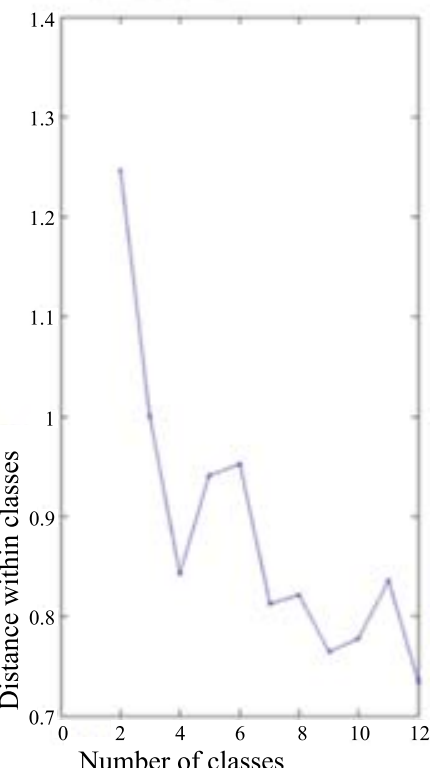

Figure 3. Grouping of classes by k-means in the self-organizing map (SOM).

Table 2. Groupings identified by an artificial neural network-self-organizing map (ANN-SOM) according to soil vulnerability classes and ecological economic zoning (EEZ) for states of the Legal Amazon.

\begin{tabular}{|c|c|}
\hline Class & Characteristics \\
\hline Class 0 & Composed mainly by areas not observed due to clouds. \\
\hline Class 1 & $\begin{array}{l}\text { High vulnerability to vegetation cover, geomorphology, precipitation, and geology. "Várzea" (floodplain) areas with secondary } \\
\text { vegetation and abandoned pastures with a high degree of regeneration, being concentrated in municipalities with a more rural } \\
\text { population and with low potential for socioeconomic development. }\end{array}$ \\
\hline Class 2 & $\begin{array}{l}\text { Areas with higher population density (in urban areas) and urban infrastructure, with better education, health and income, showing } \\
\text { the lowest rates of social inequality. Agricultural activity is quite developed and there is a reasonable production-flow infrastructure. }\end{array}$ \\
\hline Class 3 & $\begin{array}{l}\text { Mainly conditioned by the behavior of the variables geology and soil; the latter is determinant for the creation of this grouping. This } \\
\text { class does not present great socioeconomic potential, and uses in the region aim at regeneration of abandoned pastures, reforestation } \\
\text { areas, floodplains with secondary vegetation, among others. }\end{array}$ \\
\hline Class 4 & $\begin{array}{l}\text { Defined by a high rural population density, associated with variable precipitation and varied uses. It has moderately stable } \\
\text { characteristics regarding soil loss, low production runoff infrastructure, and very low human development. }\end{array}$ \\
\hline Class 5 & $\begin{array}{l}\text { These are floodplain areas, with units of use between reforestation, regeneration with pasture, secondary vegetation, and others, } \\
\text { totaling approximately } 85 \% \text { of the area. Its socioeconomic potential is quite low, as well as its population density. }\end{array}$ \\
\hline Class 6 & $\begin{array}{l}\text { High vulnerability, with a predominantly rural population and low potential for human development and urban infrastructure. } \\
\text { Modulated by natural variables (geomorphology, precipitation) and by population density (rural population). }\end{array}$ \\
\hline Class 7 & $\begin{array}{l}\text { It has a high population density, with well-developed socioeconomics and dense infrastructure, having better teaching, health and } \\
\text { income qualities, resulting in lower rates of social inequality. }\end{array}$ \\
\hline Class 8 & $\begin{array}{l}\text { High potential for human development with a good production infrastructure and low environmental vulnerability, but the population } \\
\text { of the region is much smaller. }\end{array}$ \\
\hline Class 9 & $\begin{array}{l}\text { Defined by natural variables (geology, soil, and geomorphology) and urban population, indicating a high environmental vulnerability. } \\
\text { It is a very developed region, has ample infrastructure, and land use is divided between pasture areas and secondary vegetation. }\end{array}$ \\
\hline Class 10 & $\begin{array}{l}\text { The most vulnerable among the } 12 \text { classes. It is located in lowland areas and conditioned by natural variables (soil, geomorphology, } \\
\text { and precipitation). Presents high environmental vulnerability and low socioeconomic potential. }\end{array}$ \\
\hline Classes 11 and 12 & $\begin{array}{l}\text { They exhibit intermediate behavior. In class } 11 \text {, socioeconomic issues and infrastructure are more determinant for the formation of } \\
\text { the grouping. The environmental variables geology and precipitation indicate high vulnerability. In class } 12 \text {, almost } 67 \% \text { of the area } \\
\text { is related to some type of pasture. }\end{array}$ \\
\hline
\end{tabular}


protect water sources, ensuring the maintenance of the water system (Balbinot et al., 2008).

Classes 3 and 9 have high socioeconomic potential and high vulnerability, tending towards the recovery process, favoring the regeneration of the ecosystem, which is affected by the use and occupation characteristics of the area, both past and present; by the quality of the soil; and by the existence of forest fragments nearby (Reich \& Francelino, 2012). For Balbinot Junior et al. (2009), the quality of the soil (considering favorable natural and anthropogenic conditions) refers to its ability to function within the limits of an ecosystem, sustaining biological yield, while maintaining the quality of the environment.

Most of the territory was destined for consolidation, which is represented by classes $2,7,8$, and 11 , where human potential has developed in part, but still needs to be strengthened, and the environment is mostly stable. Classes 4 and 12 present large productive areas that are moderately vulnerable, with development potential and that may be destined to expand production.

The defining variables of each class act as indicators of a given condition, pointing out the existence of vulnerabilities, potential, and trends. Their reclassification into the categories consolidation, recovery, expansion, and conservation (Figure $6 \mathrm{~A}$ ) aims to aggregate characteristics that allow relating variables, since reality is not linear or one-dimensional (Guimarães \& Feichas, 2009). For comparison, Figure $6 \mathrm{~B}$ shows the result of ecological-economic macrozoning using conventional methods (Detalhamento..., 1996; Crepani et al., 2001).

The conservation zones (Figure $6 \mathrm{~A}$ ) are related to areas surrounding rivers (lower bed) and headwaters,

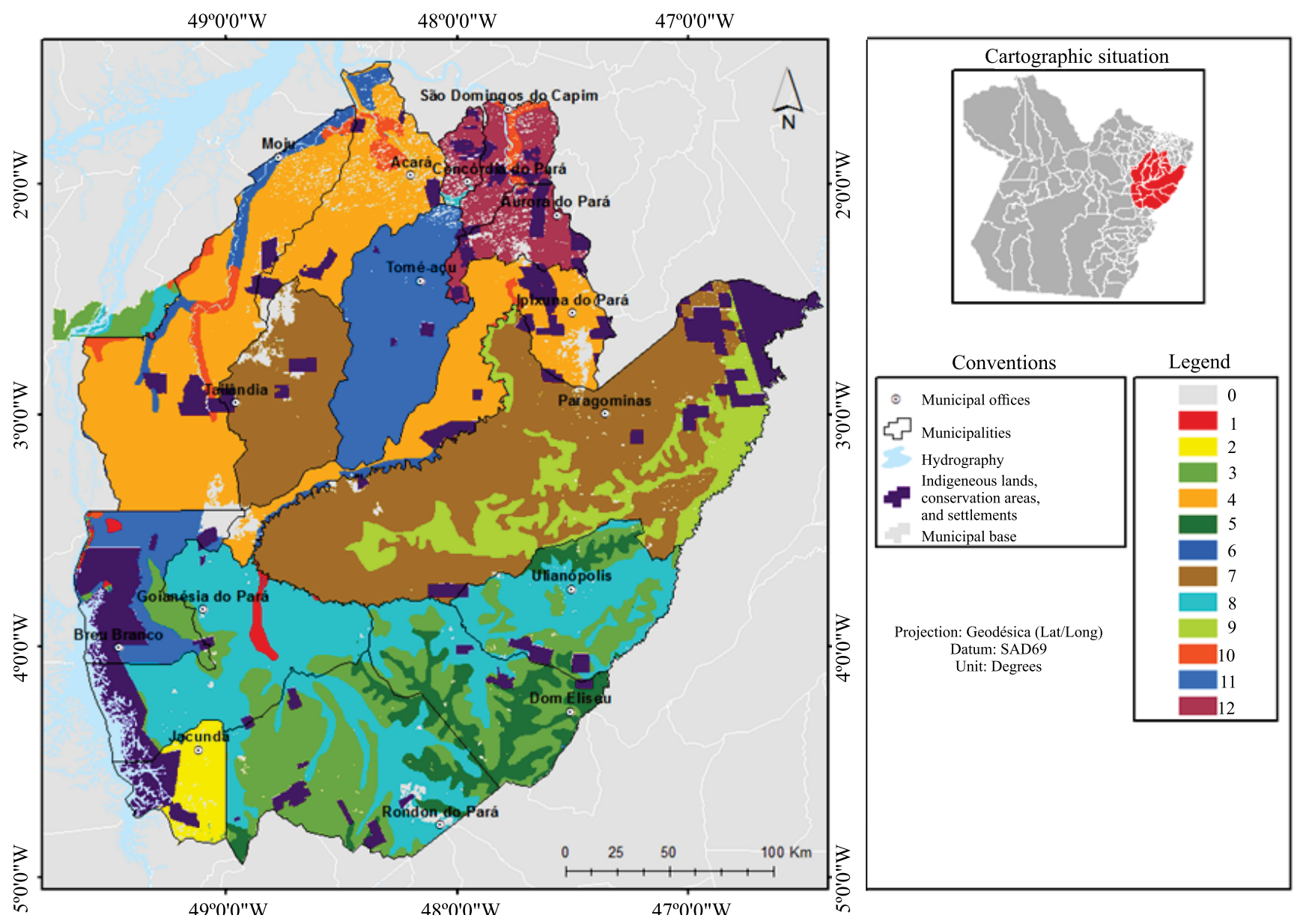

Figure 4. Grouping of classes generated by an artificial neural network-self-organizing map (ANN-SOM). 


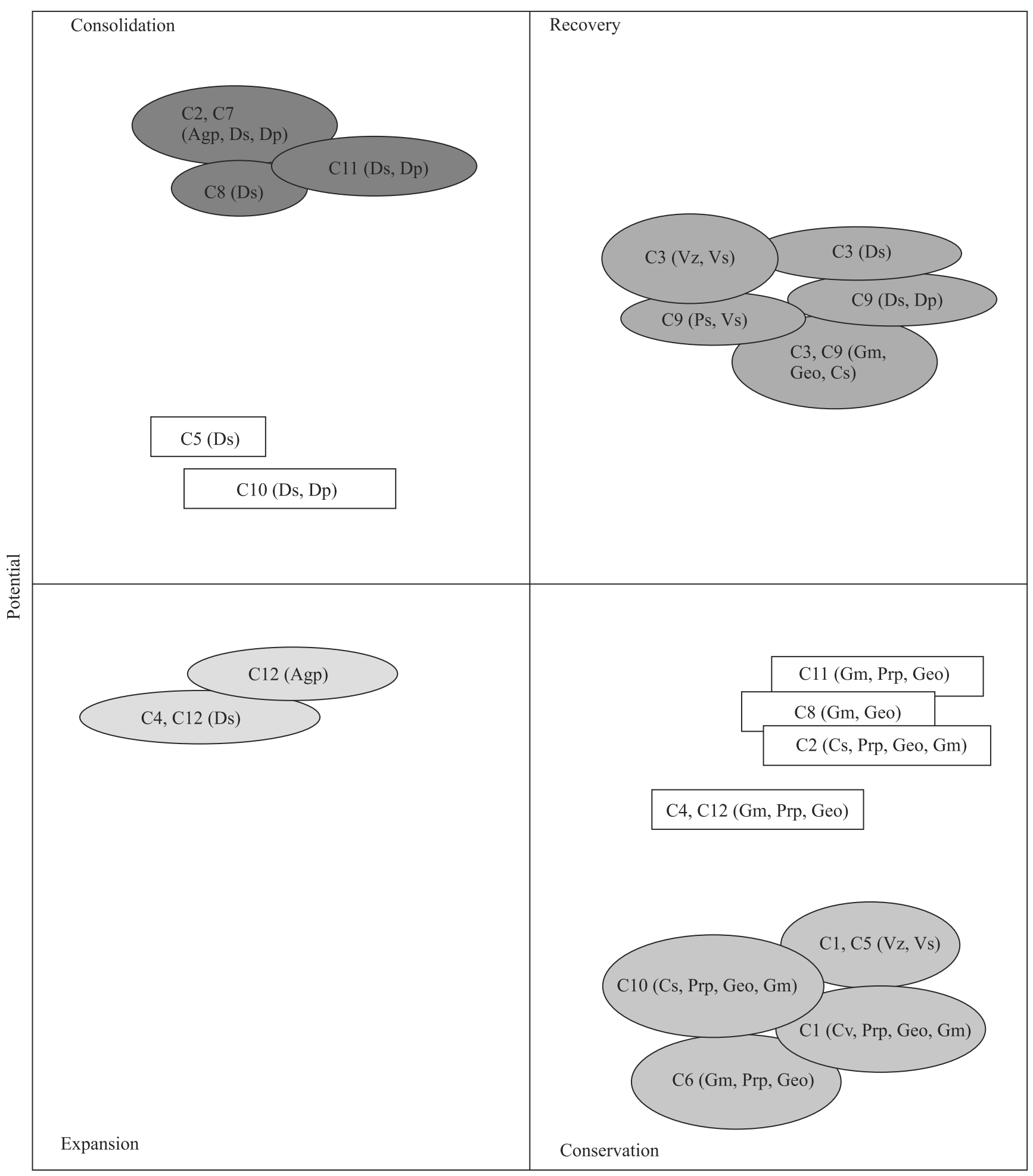

Vulnerability

Figure 5. Graphic synthesis of subsidies for land management according to four categories of analyses: consolidation, restoration, expansion and maintenance, arranged on two axes - potential and vulnerability. C, classes from 1 to 12 ; $\mathrm{Cv}$, plant cover; Gm, geomorphology; Prp, precipitation; Geo, geology; Cs, soil cover; Vz, floodplain area; Vs, secondary vegetation; Ps, pasture; Agp, farming; dp, population density; and Ds, socioeconomic development. The variables that present $\mathrm{n}>0.5$ per class were considered. 

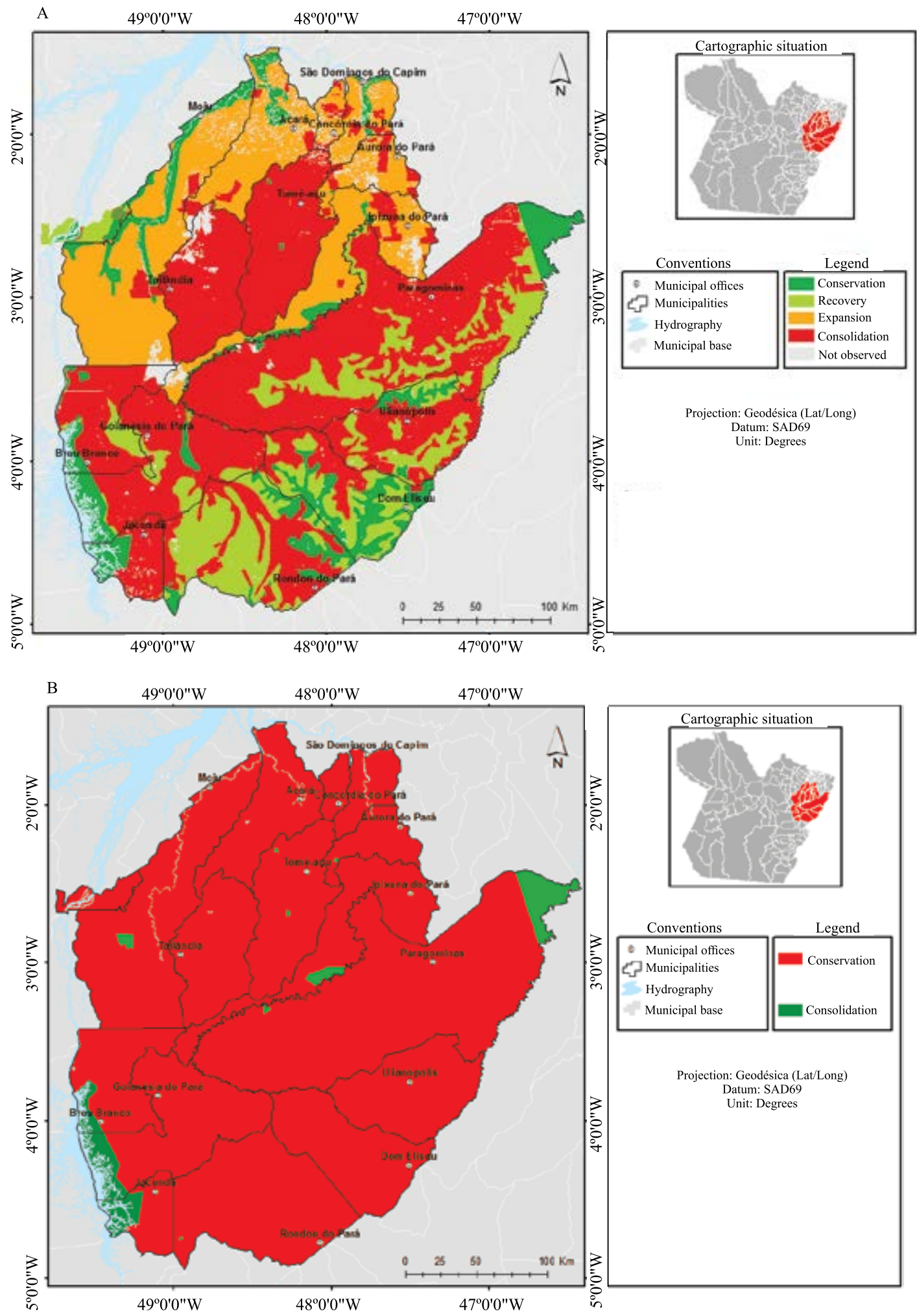

Figure 6. Synthesis of the grouping of territorial units based on the interpretation of the classes generated by an artificial neural network-self-organizing map (ANN-SOM) (A), as well as the ecological-economic macrozoning of the state of Pará, Brazil, developed by the conventional method (B). 
i.e., areas of permanent preservation. In this case, the landscape has the ecological function of preserving water resources, geological and pedological stability, and biodiversity, as well as facilitating the gene flow of fauna and flora, ensuring the well-being of human populations (Silva et al., 2014a). These populations can also enjoy the area through non-timber plant extractivism and traditional artisanal fishing (Le Tourneau \& Bursztyn, 2010).

Besides these areas, other already-established conservation units were also added, such as the environmental protection area of the Tucuruí lake, which is a sustainable use unit; and the indigenous lands of the upper Guamá river, which are areas traditionally occupied by indigenous peoples and that have the function of preserving the natural resources and productive activities of this community, leading to its physical and cultural well-being and reproduction (Ferreira et al., 2005).

The recovery areas are located in regions where the landscape has suffered degradation throughout history due to extensive livestock production (Fabbro Neto et al., 2014) and that now have been abandoned, entering often-advanced stages of succession with large portions of secondary vegetation and dirty pastures with regeneration. In addition, these areas spatially show a strong tendency towards connectivity between the landscape units of the Capim river and the Tocantins river basins, which increases biological diversity and promotes the natural dynamics of the balance of hydrological flows (Nicolodi et al., 2009).

The expansion zone is located north of the study area, bordering the economic region of the capital of the state, Belém, and the port area of Barcarena. This zone is mainly used for agricultural activities, such as palm oil production, stimulated by Programa Nacional de Produção e Uso de Biodiesel, since 2004 (Almeida, 2010). However, the region still does not have a large infrastructure of production flow for the potential development of these activities. Furthermore, planting areas are generally allocated where deforestation is already historical, not being necessary to clear or degrade areas with high regeneration (Homma, 2005), which gives more credibility to and extends the investments in the region.

The consolidation zone is where land use is already perfectly defined, having a history of occupation mainly by loggers, ranchers, and farmers. It has a high- density production infrastructure, including the BR 010, BR 222, PA 150, PA 125, and PA 256 highways, besides vicinal roads, which were determining factors for the use of the region (Ferreira et al., 2005; Le Tourneau \& Bursztyn, 2010).

The conventional zoning methodology follows the proposal of Detalhamento... (1996) and of Crepani et al. (2001), whereas the methodology developed in the present study using ANN-SOM takes into account these works, as well as those of Vesanto et al. (2000), Alves Sobrinho et al. (2011), Cecílio et al. (2013), and Leal et al. (2015). These two methodologies are compared in Table 3. A greater individualization of categories was obtained by the ANN-SOM, which may be associated with the non-linear technique used for its generation, since no political/cultural committee interfered in the creation of the classes of territorial organization.

The ANN-SOM has been used in several activities that require the creation of clusters - such as in those for the identification of ecoregions (Soares et al., 2014), exploratory analysis of multivariate geospatial data (Leal et al., 2015), regionalization of socioeconomic units, and territorial management (Silva et al., 2014a) - and in many others, from medical (Souza Neto et al., 2013) to economic sciences (Summa \& Macrini, 2014). However, the used database should be without topological errors, overlaps or gaps, following a pattern already established by Infraestrutura Nacional de Dados Espaciais (INDE, 2014). One of the potentials of ANN-SOM includes the ability to analyze the entire data set, unifying different approaches for spatial analyses in an integrated way, usually with results in greater detail than those of other methodologies (Erbek et al., 2004). Processing time is also a great advantage, as it leaves the decision-making team with more time to better plan the territorialities within the geographic space dynamics (Silva et al., 2014b).

The proposed method is the first that links EEZ with an ANN-SOM, with promising results due to a shorter development time and harmony with the socio-environmental issues of the region. The forms of visualization U-matrix and matrix of components are quite simple and easy to interpret, also allowing returning to the generated map. However, there are disadvantages related to the implementation process, since it requires specific knowledge for programming, even when the library, i.e., SOM Toolbox (Helsinki

Pesq. agropec. bras., Brasília, v.52, n.11, p.1050-1062, nov. 2017 DOI: 10.1590/S0100-204X2017001100011 
Table 3. Comparison of spatial planning methods.

\begin{tabular}{lll}
\hline Item & \multicolumn{1}{c}{ Conventional } & \multicolumn{1}{c}{ ANN-SOM $^{(1)}$} \\
\hline Data base & Preferably matrix, but can also use vector data. & $\begin{array}{l}\text { It works with tabular data that can be derived from the table } \\
\text { of the added vector. }\end{array}$ \\
\hline Normalization & $\begin{array}{l}\text { The data ranges from } 1 \text { to } 3 \text { and the environmental data } \\
\text { are subdivided into } 21 \text { unique weight intervals that are } \\
\text { subsequently divided into 5 groups; socioeconomic data ranges } \\
\text { from 1 to 3. }\end{array}$ & $\begin{array}{l}\text { All data, environmental and socioeconomic, are normalized } \\
\text { from 0 to 1, respecting the given weights. }\end{array}$ \\
\hline Processing & $\begin{array}{l}\text { It is supervised step-by-step. The team needs to check each } \\
\text { intermediate result up to the synthesis map. }\end{array}$ & $\begin{array}{l}\text { It is not supervised, simply presenting the normalized data to } \\
\text { the network so that the mathematical processing is executed } \\
\text { and the class map (grouping) is generated. }\end{array}$ \\
\hline Technique & $\begin{array}{l}\text { Linear operations appropriate to the input data may cause errors } \\
\text { in the demarcation of the output classes. }\end{array}$ & $\begin{array}{l}\text { Nonlinear operations containing a large number of associated } \\
\text { processing elements that learn to make decisions even with } \\
\text { imperfect data, being tolerant of failures and other problems } \\
\text { that may occur. }\end{array}$ \\
\hline \multirow{3}{*}{$\begin{array}{l}\text { Adjustment } \\
\text { generating the following maps: map of vulnerabilities; } \\
\text { potential map; territory sustainability map; and summary } \\
\text { map of territorial management. If one of these steps requires } \\
\text { adjustment, it is necessary to return to the lower level of the } \\
\text { process to do so. }\end{array}$} & $\begin{array}{l}\text { Once the ANN-SOM is configured, the settings are generally } \\
\text { done only in the input data. After setting, the network can be } \\
\text { run again. }\end{array}$ \\
$\begin{array}{l}\text { After all the processing and adjustment stages and the } \\
\text { participatory workshops, the synthesis map is generated, which } \\
\text { is based on socio-environmental issues, as well as on political } \\
\text { and cultural ones. }\end{array}$ & $\begin{array}{l}\text { The synthesis map is generated based on the socioeconomic } \\
\text { and environmental interpretation of the classes generated by } \\
\text { SOM, and nothing prevents this map from being discussed by } \\
\text { the local community }\end{array}$ \\
\hline
\end{tabular}

(1)ANN-SOM, artificial neural network-self-organizing map.

University of Technology, 2014) is already being developed (Spörl et al., 2011). Another problem is that, although SOM Toolbox is freely distributed, it is only programmed for MatLAB (2014), which requires a license; therefore, it would be necessary to convert it to free languages such as TerraLIB. In this sense, issues related to hardware should also be considered, because SOM processing takes-up a lot of memory and of the machine's processor.

\section{Conclusion}

The integration and analysis of social and environmental data are performed with less subjectivity when an artificial neural network-self-organizing map (ANN-SOM) is used, compared with the traditional ecological-economic zoning (EEZ) model, as shown by the obtained results.

\section{References}

ALMEIDA, C.A. de; COUTINHO, A.C.; ESQUERDO, J.C.D.M.; ADAMI, M.; VENTURIERI, A.; DINIZ, C.G.; DESSAY, N.; DURIEUX, L.; GOMES, A.R. High spatial resolution land use and land cover mapping of the Brazilian Legal Amazon in 2008 using Landsat-5/TM and MODIS data. Acta Amazonica, v.46, p.291-302, 2016. DOI: 10.1590/1809-4392201505504.

ALMEIDA, J. de P. Biodiesel o “óleo filosofal”: desafios para a educação ambiental no caldeirão do "desenvolvimento sustentável”. Rio de Janeiro: Centro Edelstein de Pesquisas Sociais, 2010. p.8-45. DOI: 10.7476/9788579820274.

ALVES SOBRINHO, T.; RODRIGUES, D.B.B.; OLIVEIRA, P.T.S. de; REBUCCI, L.C.S.; PERTUSSATTI, C.A. Estimativa da evapotranspiração de referência através de redes neurais artificiais. Revista Brasileira de Meteorologia, v.26, p.197-203, 2011. DOI: 10.1590/S0102-77862011000200004.

ARRUDA, G.P. de; DEMATTÊ, J.A.M.; CHAGAS, C. da S. Mapeamento digital de solos por redes neurais artificiais com base na relação solo-paisagem. Revista Brasileira de Ciência do Solo, v.37, p.327-338, 2013. DOI: 10.1590/S0100-06832013000200004.

BACANI, V.M.; SAKAMOTO, A.Y.; LUCHIARI, A.; QUÉNOL, H. Sensoriamento remoto e SIG aplicados à avaliação da fragilidade ambiental de bacia hidrográfica. Mercator, v.14, p.119-135, 2015. DOI: 10.4215/RM2015.1402.0008.

BALBINOT JUNIOR, A.A.; MORAES, A. de; VEIGA, M. da; PELISSARI, A.; DIECKOW, J. Integração lavoura-pecuária: intensificação de uso de áreas agrícolas. Ciência Rural, v.39, p.1925-1933, 2009. DOI: 10.1590/S0103-84782009005000107.

BALBINOT, R.; OLIVEIRA, N.K. de; VANZETTO, S.C.; PEDROSO, P.; VALERIO, A.F. O papel da floresta no ciclo hidrológico em bacias hidrográficas. Ambiência, v.4, p.131-149, 2008. 
BECKER, B.K. Geopolítica da Amazônia. Estudos Avançados, v.19, p.71-86, 2005. DOI: 10.1590/S0103-40142005000100005.

BRASIL. Decreto $n^{\circ} 7.378$, de 1 de dezembro de 2010. Aprova o Macrozoneamento Ecológico-Econômico da Amazônia Legal - Macro-ZEE da Amazônia Legal, altera o Decreto $n^{\circ} 4.297$, de 10 de julho de 2002, e dá outras providências. Diário Oficial da União, 2 dez. 2010. Seção 1, p.7-43.

BRASIL. Ministério da Integração Nacional. Subsídios para a definição da Política Nacional de Ordenamento Territorial PNOT. Brasília, 2006.

BRASIL. Ministério do Meio Ambiente. Download de dados geográficos. Available at: <http://mapas.mma.gov.br/i3geo/ datadownload.htm>. Accessed on: Oct. 122014.

BROWN, G.; FAGERHOLM, N. Empirical PPGIS/PGIS mapping of ecosystem services: a review and evaluation. Ecosystem Services, v.13, p.119-133, 2015. DOI: 10.1016/j.ecoser.2014.10.007.

CECÍlIO, R.A.; MOREIRA, M.C.; PEZZOPANE, J.E.M.; PRUSKI, F.F.; FUKUNAGA, D.C. Assessing rainfall erosivity indices through synthetic precipitation series and artificial neural networks. Anais da Academia Brasileira de Ciências, v.85, p.1523-1535, 2013. DOI: 10.1590/0001-3765201398012.

CRA. Centro Regional da Amazônia. Dados TerraClass. Available at: $<$ http://www.inpe.br/cra/projetos_pesquisas/dados_ terraclass.php>. Accessed on: Oct. 162014.

CREPANI, E.; MEDEIROS, J.S. de; HERNANDEZ FILHO, P.; FLORENZANO, T.G.; DUARTE, V.; BARBOSA, C.C.F. Sensoriamento remoto e geoprocessamento aplicados ao zoneamento ecológico-econômico e ao ordenamento territorial. São José dos Campos: Inpe, 2001. 103p.

DAVIES, D.L.; BOULDIN, D.W. A cluster separation measure. IEEE Transactions on Pattern Analysis and Machine Intelligence, v.PAMI-1, p.224-227, 1979. DOI: 10.1109/ TPAMI.1979.4766909.

DETALHAMENTO da metodologia para execução do Zoneamento Ecológico-Econômico pelos estados da Amazônia Legal. Rio de Janeiro: SAE: MMA, 1996. 40p.

ERBEK, F.S.; ÖZKAN, C.; TABERNER, M. Comparison of maximum likelihood classification method with supervised artificial neural network algorithms for land use activities. International Journal of Remote Sensing, v.25, p.1733-1748, 2004. DOI: $10.1080 / 0143116031000150077$.

FABBRO NETO, F.; MARQUES, E.M.; SANTOS, F.S.; MONTAÑO, M. Critérios técnicos e de participação social para a recuperação florestal: quais as diferenças na definição de áreas prioritárias? Engenharia Sanitária e Ambiental, v.19, p.353360, 2014. DOI: 10.1590/S1413-41522014019000000403.

FERREIRA, L.V.; VENTICINQUE, E.; ALMEIDA, S. O desmatamento na Amazônia e a importância das áreas protegidas. Estudos Avançados, v.19, p.157-166, 2005. DOI: 10.1590/S010340142005000100010.

GUIMARÃES, R.P.; FEICHAS, S.A.Q. Desafios na construção de indicadores de sustentabilidade. Ambiente e Sociedade, v.12, p.307-323, 2009. DOI: 10.1590/S1414-753X2009000200007.
HAYES, N.; RAJÃO, R. Competing institutional logics and sustainable development: the case of geographic information systems in Brazil's Amazon region. Information Technology for Development,v.17, p.4-23, 2011. DOI: $10.1080 / 02681102.2010 .511701$.

HELSINKI UNIVERSITY OF TECHNOLOGY. Laboratory of Computer and Information Science. [SOM Toolbox 2.0]. Available at: $<$ http://www.cis.hut.fi/somtoolbox/>. Accessed on: Nov. 102014.

HOMMA, A.K.O. Amazônia: como aproveitar os benefícios da destruição? Estudos Avançados, v.19, p.115-135, 2005. DOI: 10.1590/S0103-40142005000200007.

IBGE. Instituto Brasileiro de Geografia e Estatística. Downloads: geociências. Available at: <http://downloads.ibge.gov.br/ downloads_geociencias.htm>. Accessed on: Oct. 6 2014a.

IBGE. Instituto Brasileiro de Geografia e Estatística. Sistema IBGE de Recuperação Automática - SIDRA. Available at: <http://www.sidra.ibge.gov.br/bda/tabela/protabl. asp? $=1613 \& \mathrm{z}=\mathrm{p} \& \mathrm{o}=28 \& \mathrm{i}=\mathrm{P}>$. Accessed on: Oct. $122014 \mathrm{~b}$.

INDE. Infraestrutura Nacional de Dados Espaciais. Available at: <http://www.inde.gov.br/>. Accessed on: Oct. 72014.

INPE. Instituto Nacional de Pesquisas Espaciais. TerraView. 4.2.2. São José dos Campos, [2014].

LE TOURNEAU, F.-M.; BURSZTYN, M. Assentamentos rurais na Amazônia: contradições entre a política agrária e a política ambiental. Ambiente e Sociedade, v.13, p.111-130, 2010. DOI: 10.1590/S1414-753X2010000100008.

LEAL, A.J.F.; MIGUEL, E.P.; BAIO, F.H.R.; NEVES, D. de C.; LEAL, U.A.S. Redes neurais artificiais na predição da produtividade de milho e definição de sítios de manejo diferenciado por meio de atributos do solo. Bragantia, v.74, p.436-444, 2015. DOI: 10.1590/1678-4499.0140.

MARTINS, D.E.G.; CAMARGO-ZORRO, M.; SOUZA FILHO, P.W.M.; CINTRA, I.H.A.; SILVA, K.C.A. Spatial distribution of southern brown shrimp (Farfantepenaeus subtilis) on the Amazon continental shelf: a fishery, marine geology and GIS integrated approach. Brazilian Journal of Oceanography, v.63, p.397-406, 2015. DOI: 10.1590/S1679-87592015090106304.

MATLAB. Available at: <https://www.mathworks.com/products/ matlab.html>. Accessed on: Oct. 122014.

NASA. National Aeronautics and Space Administration. Precipitation Measurement Missions. TRMM Data Downloads. Available at: <https://pmm.nasa.gov/data-access/downloads/ trmm>. Accessed on: Oct. 62014.

NICOLODI, J.L.; ZAMBONI, A.; BARROSO, G.F. Gestão integrada de bacias hidrográficas e zonas costeiras no Brasil: implicações para a Região Hidrográfica Amazônica. Revista de Gestão Costeira Integrada, v.9, p.9-32, 2009. DOI: 10.5894/ rgcil15.

OBT. Coordenação-Geral de Observação da Terra. Projeto PRODES: monitoramento da Floresta Amazônica brasileira por satélite. Available at: $<$ http://www.obt.inpe.br/prodes/index.php $>$. Accessed on: Oct. 62014.

Pesq. agropec. bras., Brasília, v.52, n.11, p.1050-1062, nov. 2017 DOI: $10.1590 / \mathrm{S} 0100-204 \mathrm{X} 2017001100011$ 
PEREIRA, J.R.; FERREIRA, P.A.; VILAS BOAS, A.A.; OLIVEIRA, E.R. de; CARDOSO, R.F. Gestão social dos territórios da cidadania: o zoneamento ecológico-econômico como instrumento de gestão do território noroeste de Minas Gerais. Cadernos EBAPE.BR, v.9, p.724-747, 2011. DOI: 10.1590/ S1679-39512011000300004.

PNUD. Programa das Nações Unidas para o Desenvolvimento no Brasil. Available at: <http://www.pnud.org.br/>. Accessed on: Oct. 122014.

PARÁ. Secretaria de Estado de Meio Ambiente. Zoneamento Ecológico-Econômico do Estado do Pará: Zona Oeste, Zona Leste e Calha Norte. [Belém]: Sema, 2012.

POSTGRESQL GLOBAL DEVELOPMENT GROUP. PostgreSQL. Available at: <https://www.postgresql.org/ download/windows/>. Accessed on: Oct. 62014.

POZZEBON, M.; TELLO ROZAS, S.; DELGADO, N.A. Use and consequences of participatory GIS in a Mexican municipality: applying a multilevel framework. Revista de Administração de Empresas, v.55, p.290-303, 2015. DOI: 10.1590/S0034759020150305 .

REICH, M.; FRANCELINO, M.R. Avaliação do potencial de recuperação de áreas alteradas em Áreas de Proteção Permanente de cursos d'água no município de Rio Branco, Acre. Boletim do Museu Paraense Emílio Goeldi. Ciências Naturais, v.7, p.157168, 2012.

REIS, D.R.; PLANGG, R.; TUNDISI, J.G.; QUEVEDO, D.M. Physical characterization of a watershed through GIS: a study in the Schmidt stream, Brazil. Brazilian Journal of Biology, v.75, p.S16-S29, 2015. Supplement 2. DOI: 10.1590/1519-6984.01313suppl.

SAATY, T.L. Método de análise hierárquica. São Paulo: McGrawHill, 1991. 367p.

SILVA, D.J.; SANTOS-FILHO, M.; CANALE, G.R. The importance of remnant native vegetation of Amazonian submontane forest for the conservation of lizards. Brazilian Journal of Biology, v.74, p.523-528, 2014a. DOI: 10.1590/ bjb.2014.0095.

SILVA, P.R.; ACERBI JUNIOR, F.W.; CARVALHO, L.M.T. de; SCOLFORO, J.R.S. Use of artificial neural networks and geographic objects for classifying remote sensing imagery. Cerne, v.20, p.267-276, 2014b. DOI: 10.1590/01047760.201420021615.

SOARES, F.C.; ROBAINA, A.D.; PEITER, M.X.; RUSSI, J.L.; VIVAN, G.A. Redes neurais artificiais na estimativa da retenção de água do solo. Ciência Rural, v.44, p.293-300, 2014. DOI: 10.1590/S0103-84782014000200016.

SOUZA NETO, J.; CARVALHO, J.L.A. de; ROCHA, A.F. da; JUNQUEIRA JUNIOR, L.F.; NASCIMENTO, F.A. de O. Sistema de apoio ao diagnóstico da Doença de Chagas baseado em escalogramas e redes neurais auto-organizáveis. Revista Brasileira de Engenharia Biomédica, v.29, p.242-253, 2013. DOI: 10.4322/rbeb.2013.027.

SOUZA, J. do S.A. de; MEDEIROS, J.S. de. Modelagem da carta síntese de subsídios à gestão do território do sul do Amapá, através de análise geográfica em Spring. Boletim do Museu Paraense Emílio Goeldi. Ciências Naturais, v.1, p.141-144, 2003.

SPÖRL, C.; CASTRO, E.G.; LUCHIARI, A. Aplicação de redes neurais artificiais na construção de modelos de fragilidade ambiental. Revista do Departamento de Geografia, v.21, p.113135, 2011. DOI: 10.7154/RDG.2011.0021.0006.

SUMMA, R.F.; MACRINI, L. Os determinantes da inflação brasileira recente: estimações utilizando redes neurais. Nova Economia, v.24, p.279-296, 2014. DOI: 10.1590/0103-6351/1332.

TORNQUIST, C.G.; GASSMAN, P.W.; MIELNICZUK, J.; GIASSON, E.; CAMPBELL, T. Spatially explicit simulations of soil C dynamics in Southern Brazil: integrating century and GIS with i-Century. Geoderma, v.150, p.404-414, 2009. DOI: 10.1016/j.geoderma.2009.03.001.

VERÍSSIMO, A.; SOUZA JR., C. (Coord.). Detalhamento do Macrozoneamento ecológico económico do Estado do Pará: áreas para produção florestal manejada: relatório preliminar para discussão. Belém: Secretaria Especial de Estado de Produção, 2006.

VESANTO, J.; HIMBERG, J.; ALHONIEMI, E.; PARHANKANGAS, J. SOM Toolbox for Matlab 5. Finland: Helsinki University of Technology, 2000. (Report A57).

WOODWARD, J.F. Data and phenomena: a restatement and defense. Synthese, v.182, p.165-179, 2011. DOI: 10.1007/s11229009-9618-5.

$\overline{\text { Received on March 11, } 2016 \text { and accepted on October 21, } 2016}$

Pesq. agropec. bras., Brasília, v.52, n.11, p.1050-1062, nov. 2017

DOI: 10.1590/S0100-204X2017001100011 